\title{
MEMBANGUN KEWIRAUSAIIAAN DALAM PERSPEKTIF AGRIBISNIS DI ERA GLOBALISASI
}

\author{
Imaculata Fatima \\ Program Studi Agroekoteknologi Fakultas Pertanian Universitas Flores \\ Usima_uniflor@yahoo.co.id
}

\section{SUMMARY \\ Building Enterpreneurship in the Prospective of Agribusiness Toward Global Era}

To face the economic problems in this global era, agriculture sector can support the needs of many people in Indonesia, particulary those who have low economic background. Recently most farmers have worked hard to increase their product. However, they often find have problems or handicaps such as : (1) human resource is still low; (2) financial problems; (3) land is not enough to produce commodities; (4) infrastructures are not availabel enough; (5) appropriate technologies are not enough; (6) networking system of agriculture is not established yet to all agriculture sector; (7) most of the farmers are depending on the natural support; (8) skill, spirit enterpreneurship and sense of self support of the farmers are not optimalized.

Regarding to these problems, in fact, most farmers are developing their agriculture sectors wihout considering the quality of their products which is very important to the consumers, the second problem is economic global which is running fast. This can cause problems to the farmers. It is therefore, all the farmers should be motivated to improve their capability on agriculture and their feeling confidence. Bassed on the issues, this article focuses on the single problem like "is it relevant to give understanding about business which oriented to agribusiness toward global area?"

It is sum up that in the global marketing, agriculture sector is relevant to wake the spirit, enterpreneurship ability of the farmers and oriented to agribusiness. Then they should consider the effeciency, competitive, productivuty, viable, marketing strategic and self-support in order to place themselves well either in the local, regional or national level, even in the international level.

\section{Key Word : Enterpreneurship, Agribusiness and Global era.}

\section{PENDAHULUAN}

Menghadapi kondisi perekonomian yang tidak menentu saat ini, usaha pertanian justru masih mampu memberikan kontribusi bagi pemenuhan kebutuhan masyarakat kelas ekonomi kebawah. Berbagai upaya telah dilakukan oleh para pelaku pertanian untuk terus meningkatkan hasil - hasilnya. Namun untuk mendapatkan hasil pertanian tersebut para petani sering kali berbenturan dengan berbagai kendala diantaranya : (I) kualitas sumber daya manusia yang masih rendah, (2) modal yang terbatas, (3) lahan yang sempit, (4) infrastruktur yang belum optimal, (5) teknologi tepat guna yang terbatas, (6) system informasi pertanian belum tersedia secara merata, (7) usaha pertanian lebih banyak bergantung pada air hujan, (8) semangat, jiwa dan kemampuan kewirausahaan serta kemandirian dalam usaha pertanian belum optimal.

Terkait dengan kendala tersebut, sebagian pengusaha pertanian cenderung untuk mengembangkan usahanya tanpa memperhatikan kebutuhan konsumen atau pasar dalam hal kualitas yang pada gilirannya posis tawar produk pertanian kurang memiliki nilai atau tidak kompotitif. Menghadapi era globalisasi dan perubahan tatanan perekonomian perekonomian dunia yang sedemikian cepat berbagai peluang dan tantangan yang akan dihadapi. Oleh karena itu setiap pelaku usaha pertanian harus merespon secara positif dan berusaha untuk memiliki semangat dan berusaha untuk memiliki semangat, jiwa dan kemampuan berwirausaha. Usaha pertanian saat ini dan yang akan datang perlu melakukan dan mempertimbangkan daya saing yang kuat karena jika tidak demikian maka perekonomian secara nasional akan di remote oleh kekuatan luar.

Perubahan tatanan perekonomian dunia dengan disetujuinya Putaran Uruguay dan General Agreement of Tariffs and Trade (GATT) serta pembentukan badan perdagangan dunia World Trade Organization (WTO), perdagangan bebas akan menjadi mekanisme pertukaran barang dan jasa dalam perekonomian dunia. Deklarasi para pemimpin ekonomi APEC di Bogor tanggal 15 Nopember 1994 yang ditindaklanjuti dengan pertemuan di Osaka, Jepang pada Nopember 1995 telah disepakati untuk melaksanakan perdagangan bebas selambat - lambatnya tahun 2010 bagi ekonomi maju dan 2020 bagi ekonomi yang sedang berkembang termasuk Indonesia. Kesepakatan ini dapat menjadi peluang sekaligus 
tantangan bagi para pelaku pertanian khususnya dan juga masyarakat pada umumnya

Mengingat berbagai faktor penghambat dalam pembangunan pertanian yang berkualitas terutama yang merupakan faktor terlemah masyarakat dewasa ini adalah kualitas sumber daya manusia yang berhubungan erat dengan kemampuan teknis dan manajerial yang dirasakan masih kurang sehingga perlu dilakukan upaya peningkatan semangat, jiwa dan kemampuan berwirausaha.

Mencermati permasalahan tersebut maka kiat usaha pertanian dalam menghadapi pasar bebes atau era globalisasi adalah efisiensi, kompotitif, produktif, viable, melakukan sinergi, marketing strategi dan kemandirian. Untuk itu usaha saat ini sudah relevan untuk diarahkan pada pengembangan kewirausahaan beragribisnis a gar mampu memposisikan diri dalam pasar bebas yang juga sangat berpengaruh pada pasar lokal.

Bertitik tolak pada penjabaran tersebut maka permasalahannya adalah "Apakah relevan memberikan pemahaman kepada semua pelaku usaha pertanian untuk membangun kewirausahaan dalam perspektif agribisnis menuju era globalisasi?".

\section{ULASAN}

Saat ini masih banyak petani yang melakukan usaha pertaniannya sebagai rutinitas, sehingga orientasinya masih berkutat pada pembangunan pertanian berbasis pengembangan komoditas, upaya peningkatan kuantitas produksi pertanian, pendekatan pada komoditas, perencanaan Top - Down, kendali oleh pemerintah. Kondisi tersebut dapat berdampak matinya kreativitas dan inovasi yang dapat merugikan para petani, pelaku usaha pertanian dan usaha agribisnis. Perlu dipahami bahwa pengusaha pertanian identik dengan pelaku usaha agribisnis. Dalam rangka mempersiapkan usaha agribisnis diperlukan sikap mental wirausaha yang tangguh agar usahanya dapat berkelanjutan. Untuk memahami tentang kewirausahaan dalam perspektif agribisnis diera globalisasi selanjutnya akan dibahas berikut ini :

\section{Konsep Kewirausahaan}

Kewirausahaan adalah semangat, sikap, perilaku dan kemampuan seseorang dalam menangani usaha dan atau kegiatan yang mengarah pada upaya mencari, menciptakan, menerapkan cara kerja, teknologi dan produk baru dengan meningkatkan efisiensi untuk memberikan pelayanan yang lebih baik dan memberikan keuntungan.
Wirausaha adalah seseorang yang mempunyai semangat, sikap, perilaku dan kemampuan kewirausahaan. Pengusaha adalah seseorang yang berusaha mencari keuntungan dengan memiliki dan mengelola sendiri perusahaannya atau bersama orang lain dengan atau tanpa bantuan menejemen professional.

Dalam pengembangan kewirausahaan, beberapa komponen yang perlu diperhatikan adalah :

(1) Mengidentifikasi, memilih dan memberikan dukungan kepada pengusaha - pengusaha potensial untuk mengembangkan usaha baru.

(2) Memfasilitasi pertumbuhan pengusaha - pengusaha yang ada

(3) Memberikan kontribusi kearah pembangunan wirausaha

(4) Memfasilitasi terciptanya iklim usaha yang kondusif bagi UKM pemula dan dalam pertumbuhan

\section{Konsep Agribisnis}

Kata "Agribisnis" saat ini sangat santer diperbincangkan. Namun dalam kenyataannya masih banyak orang yang tidak memahaminya secara benar yakni hanya sebatas pemahaman agribisnis sebagai perdagangan atau pemasaran hasil pertanian.

Konsep agribisnis sesungguhnya adalah konsep yang utuh dalam arti mencakup totalitas dari keseluruhan proses dalam usaha yang berkaitan dengan pertanian. - Proses tersebut dimulai dari proses produksi, mengolah hasil, pemasaran dan aktivitas lain yang berkaitan an kegiatan pertanian.

92 Banyak pendapat tentang batasan dan ruang lingkup agribisnis, tergantung pada unit dan tujuan analisis. Secara tradisional, Biere (1988) agribisnis diartikan sebagai aktivitas - aktivitas di luar pintu gerbang usaha tani (beyond the farm gate, off-fann) yang meliputi kegiatan industri dan perdagangan sarana produksi usaha tani, kegiatan industri yang mengolah produk pertanian primer menjadi produk olahan beserta perdagangannya dan kegiatan yang menyediakan jasa yang dibutuhkan seperti misalnya perbankan, angkutan, asuransi atau penyimpanan.

Adanya perubahan - perubahan dalam struktur produksi pertanian dan semakin meningkatnya kebutuhan koordinasi baik secara horizontal maupun vertikar dalam sektor agribisnis dipandang perlu untuk memperluas definisi tradisional di atas. Definisi yang lebih lengkap diberikan oleh pencetus awal istilah agribisnis yaitu Davis dan Goldberg (1957) sebagai berikut "Agribusiness is the sum total of all operations involved in the nanufacture and 
distribution of farm supplies; production activities on the farm; and storage, processing and distribution of commodities and items made from them". Definisi inilah yang sekarang sering digunakan dalam literatur agribisnis (Sonka dan Hudson, 1989)

Agribisnis merupakan suatu sistem yang terdiri atas sub sistem hulu, usaha tani, hilir dan penunjang. Menurut Saragih dalam Pasaribu (1999). batasan agribisnis adalah sistem yang utuh dan saling terkait di antara seluruh kegiatan ekonomi yang terkait langsung dengan kegiatan pertanian.

Agribisnis diartikan sebagai sebuah sistem yang terdiri dari unsur - unsur kegiatan : (1) pra-panen, (2) panen, (3) pasca panen dan (4) pemasaran. Sebagai sebuah sistem, kegiatan agribisnis tidak dapat dipisahkan satu dengan yang lainnya, saling menyatu dan terkait. Terputusnya pada salah satu bagian akan mengakibatkan timpangnya sistem tersebut. Sedangkan agribisnis merupakan sektor pertanian, termasuk perikanan dan kehutanan serta bagian dari sektor industri. Sektor pertanian dan perpaduan antara kedua sektor inilah yang akan menciptakan pertumbuhan ekonomi yang baik secara nasional (Sumodiningrat,2000).

\section{Pentingnya Pengembangan Agribisnis}

Mengingat agribisnis merupakan aktivitas dibidang usaha pertanian, maka perlu dipahami mengapa sektor pertanian sampai saat ini masih memegang peranan penting. Adapun alasanny sebagai berikut : a) Sektor pertanian masih memberikan kontribusi yang tinggi terhadap Produk Domestik Bruto; b) Sektor pertanian masih mampu menyediakan lapangan kerja terutama didaerah pedesaan; c) Sektor pertanian mampu menyediakan keragaman menu pangan yang mempengaruhi pola konsumsi dan gizi masyarakat; d) Sektor pertanian mampu mendukung sektor industri, baik industri hulu maupn hilir; e) Ekspor hasil pertanian masih memberikan kontribusi terbesar bagi devisa negara.

Mempertimbangkan kepentingan agribisnis tersebut, maka saat ini agribisnis layak dikembangkan karena didukung kondisi daerah yang menguntungkan, antara lain :

1. Letak wilayah Indonesia berada di garis katulistiwa menyebabkan sinar matahari tersedia cukup bagi perkembangan usaha pertanian, suhu tidak terlalu panas dan agroklimatnya relatif baik sehingga kondisi lahan relatif subur
2. Letak Indonesia berada di luar zone angin taifun yang sering melanda negara Filipina, Taiwan dan Jepang

3. Keadaan sarana prasarana seperti daerah aliran sungai, tersedianya irigasi, jalan pedesaan yang relatif baik yang mendukung perkembangan agribisnis

4. Adanya kemampuan politik pemerintah yang menjadikan sektor pertanian menjadi sektor yang mendapatkan prioritas

Pengembangan agribisnis ditinjau dari kondisi daerah memang menguntungkan namun bukan berarti semuanya dapat berjalàn dengan lancar. Dalam pelaksanaannya aktivitas agribisnis juga menghadapi berbagai hambatan.

Hambatan - hambatan Pengembangan Agribisnis dari Berbagai Aspek

1. Pola produksi pada beberapa produk pertanian tertentu terletak pada lokasi yang terpencar sehingga menyulitkan pembinaan dan tercapainya efisiensi pada skala tertentu.

2. Sarana dan prasarana, khususnya pada daerah luar Jawa terasa belum memadai sehingga sulit untuk mencapai efisien usaha pertanian

3. Akibat dari hal tersebut diatas maka biaya transportasi menjadi lebih tinggi

4. Sering dijumpai adanya pemusatan agroindustri pada kota - kota besar sehingga nilai bahan baku untuk mencapai lokasi agribisnis menjadi mahal

5. Sistem kelembagaan, terutama di pedesaan terasa masih lemah sehingga kondisi seperti ini kurang mendukung berkembangnya kegiatan agribisnis

\section{Kewirausahaan dalam Perspektif Agribisnis di Era Globalisasi}

Kewirausahaan dianggap sebagai titik temunya peluang dengan persiapan yang dimulai dengan pengembangan ide, mewujudkan impian, mengalokasi sumber daya yang terbatas dan memberi nilai lebih kepada dirinya dan masyarakat.Krisis ekonomi sekarang ini banyak melanda usaha - usaha yang menggunakan komponen impor tinggi. Sebaliknya memberi peluang usaha - usaha yang berbasis sumber daya setempat yang berpotensi ekspor dan yang melakukan sinergisme termasuk didalamnya adalah peluang usaha dibidang pertanian.

1. Pentingnya penguasaan teknologi dan intormasi. Aspek ini berjalan dengan begitu cepat dan pengaruhnya dapat menyentuh berbagai aspek kehidupan. Oleh karena itu sektor pertanian perlu dibangun dengan memantaatkan teknologi dan intormasi untuk mewujudkan pertanian modern. Ciri petani 
modern dan konvensional dapat dijabarkan

sebagai berikut :

Tabel 1. Ciri petani konvensional dan petani modern

\begin{tabular}{|c|c|c|c|}
\hline \multirow{2}{*}{ No } & \multirow{2}{*}{ Variabel } & \multicolumn{2}{|c|}{ Usaha Tani } \\
\hline & & Skala sempit/Konvensional & Skala relatif luas Modern \\
\hline 1 & Lahan & Relatif sempit & Relatif luas \\
\hline 2 & Status lahan & Milik, sewa, sakap & Umumnya hak guna usaha \\
\hline 3 & Pengelolaan lahan & $\begin{array}{l}\text { Oleh petani sendiri, sebagian } \\
\text { tenaga upah, sederhana }\end{array}$ & $\begin{array}{l}\text { Kebanyakan swasta, tenaga upah, } \\
\text { rumit }\end{array}$ \\
\hline 4 & Jenis tanaman & $\begin{array}{l}\text { Campuran, monocultur tanaman } \\
\text { pangan }\end{array}$ & Monokultur tanaman perdagangan \\
\hline 5 & Teknologi & Sederhana & Modern \\
\hline 6 & Teknik budidaya & Tradisional & Modern \\
\hline 7 & Tenaga kerja & Manusia, ternak, mekanik & Mekanik, mesin \\
\hline 8 & Permodalan & Padat karya & Padat modal \\
\hline 9 & Proses produksi & Di alam terbuka, tergantung alam & $\begin{array}{l}\text { Di alam terbuka, tergantung alam } \\
\text { dan dalam ruangan, tidak } \\
\text { tergantung dengan alam }\end{array}$ \\
\hline 10 & Pengelolan & Sederhana & Modern \\
\hline 11 & $\begin{array}{l}\text { Cara pengambilan } \\
\text { keputusan }\end{array}$ & Cepat dan jangka pendek & Cepat dan jangka panjang \\
\hline 12 & Standarisasi produksi & Relatif sulit & Relatif murah \\
\hline 13 & Perputaran modal & Lama & Cepat \\
\hline 14 & Pasar & Domestik & Orientasi ekspor \\
\hline
\end{tabular}

Sumber : Soekartawi (2005)

2. Meningkatnya jumlah Key Players disektor pertanian akibatnya pertanian bukan menjadi sektor yang ditangani oleh Departemen Pertanian tetapi oleh banyak Departemen seperti Departemen perdagangan, Perhubungan, Keuangan dan sebagainya. Oleh karena itu perlu adanya koordinasi yang baik diantara lembanga lembaga tersebut. Masalah pertanian bukan saja milik petani tetapi juga memerlukan partisipasi pedagang, pemerintah daerah, instansi yang menyalurkan sarana produksi yang mengatur irigasi, yang membeli produk pertanian dan sebagainya. Makin majunya teknologi dan informasi maka makin modernnya sektor pertanian yang mengakibatkan dinamika koordinasi atau kerja sama antar lembaga dan produsen menjadi kritis.

3. Meningklatnya perubahan preferensi konsumen pada produk pertanian. Perubahan preferensi konsumen perlu diantisipasi secara cepat. Hal ini dapat ditinjau dari aspek ukuran, rasa, kadar, warna, aroma dan hiegenis.

4. Perubahan harga yang cepat karena munculnya Key Players baru diperdagangan produk - produk pertanian tropis seperti mangga, nanas dan sebagainya.

5. Menyempitnya lahan pertanian. Kondisi umum yang berkembang di Indonesia adalah masalahnya bukan saja semakin menyempitnya lahan pertanian tetapi jumlah petani yang menguasai lahan kurang dari 0,5 ha semakin bertambah. Hal ini terjadi karena 
masyarakat petani merasa produk pertanian tidak memiliki nilai ekonomis yang menguntungkan sehingga kecenderungannya adalah mengkonversikan lahan pertanian menjadi bangunan pabrik tau lainnya.

6. Meningkatnya kesadaran kesehatan menyebabkan perubahan kualitas produk pertanian. Dengan demikian maka produk pertanian dapat mengantisipasi untuk dapat memenuhi kebutuhan tersebut, misalnya menghasilkan produk pertanian organik yang semakin diminati, menghasilkan produk pertanian yang bermanfaat bagi kesehatan seperti VCO dan sebagainya

7. Perubahan iklim/cuaca yang kini mulai suiit diprediksi, agar produsen pantai mengantisipasinya

8. Pembiayaan usaha tani yang sudah terlanjur mahal karena ekonomi biaya tinggi, upaya efisiensi sangat diperlukan, usaha bebas anorganik atau mengurangi input.

Berdasarkan uraian di atas maka pertanian masa depan yang mampu menghadapi tantangan global adalah 1) diusahakan dilahan sempit dengan teknologi modern, 2) produknya memiliki nilai tambah yang tinggi, 3) produk yang dijual sebaiknya dari hasil diversifikasi yang vertikal maupun horizontal (misal kelapa yang dijual adalah produk derivatnya seperti minyak kelapa, tepung kelap, keset, jok mobil, spring bed, souvenir dan sebagainya), 4) produk pertanian yang menguntungkan dan memilki prospek pasar.

Dari beberapa ciri produk pertanian di era global maka ada beberapa unsur yang perlu dikemukakan yaitu :

1) Kemampuan mengakses teknologi clan informasi

Kemampuan mengakses teknologi merupakan prasyatrat dalam pengembangan pertanian yang berkelanjutan. Penggunaan teknologi akan menggunakan input menjadi output yang diinginkan (Gumbira-sa'id, 2001). Teknologi tersebut memiliki emapt komponen sebagai berikut:

a. Teclmoware, merupakan bagian dari fasilitas fisik seperti mesin serta peralatan yang dapat meningkatkan kekuatan manusia serta mengontrol jalannya operasi

b. Humanware, manusia yang mempunyai kemampuan seperti : keterampilan, keahlian dan kreativitas yang memperlihatkan nilai sesungguhnya dari sumber daya manusia

c. Infoware, fakta dan informasi yang tercatat seperti design, spesifikasi dan cetak biru yang memungkinkan cepat belajar seperti dari berbagai informasi data base

d. Orgaware, metode, jaringan kerja sama (networking) serta berbagai praktik yang berfungsi untuk mengordinasikan kegiatan untuk mencapai apa yang diingikan.

\section{2) Kemampuan berkompetisi}

Kemampuan daya saing suatu negar (termasuk di dalamnya comford level, security level dan ROI di suatu negara) merupakan informasi bagi investor untuk menentukan kemana dananya akan diinvestasikan. Secara umum ada dua institusi yang secara reguler melakuakan pengukuran kekuatan daya saing yaitu I) World Economic Forum (WEF) dengan dua jenis indeks yaitu Global competitiveness index (GCI) dan Business competitiveness index (BCI) dan 2) International Institute for Management Development (IMD) yakni World Competitiveness Year Book

Kekuatan daya saing ditunjukkan dengan rendahya peringkat atau sebaliknya semakin tinggi ranking semakin buruk daya saing. Berdasarkan data GCI tahun 2003, daya saing Indonesia terus menurun dari peringkat 43 tahun 2000 menjadi 72 pada tahun 2003. Berdasarkan BCI dari peringkat 55 tahun 2001 menjadi peringkat 60 tahun 2003. Sementara peringkat menurut WBC dari peringkat 25 tahun 1999 menjadi peringkat 28 pada tahun 200.

Iklim investasi yang buruk bagi pertanian di Indonesia pada dasarnya bersumber pada hal hal berikut : 1) Keberpihakan pemerintah pada sektor pertanian masih kurang. Hal ini terlihat dari : a) Keinginan memiliki industri pertanian yang tangguh seperti Thailand misalnya, tidak disertai dengan komitmen alikasi anggaran yang memadai untuk riset; b) kebijakan kredit perbankan masih dibatasi untuk bidang pertanian; c) kredit untuk pertanian rakyat tidak memadai sehingga mas uknya jasa tengkulak yang mengeluarkan cost jauh lebih tinggi kepada petani; 2) Rendahnya pendidikan bagi tenaga kerja; 3) penerapan modernisasi yang canggih di pertanian menimbulkan keraguan bagi petani terhadap value yang diterima; 4) infrastruktur yang memadai kurang tersedia; 5) harga dikendalikan oleh pemerintah sedangkan biaya tidak

Dengan mempertimbangkan dinamika dan preferensi konsumen yang kian cepat diera global saat ini maka usaha pertanian yang dulunya secara konvensional perlu diperbaharui dengan menerapkan teknologi terutama pada lahan lahan sempit atau di daerah perkotaan yang areal pertaniannya semakin berkurang. 
Untuk memenuhi preferensi konsumen yang kian berubah maka Mosher (1960) mengemukakan 5 faktor pokok yang masih relevan sampai saat ini untuk dipenuhi yaitu : a) adanya pasar produk pertanian; b) adanya teknologi yang selalu berubah dan dikuasai petani; c) adanya sarana produksi secara lokal; d) adanya intensif produksi bagi petani; dan e) adanya transport yang memadai.

Jika dikaitkan dengan kemajuan ilmu dan teknologi yang mempengaruhi mindset para petani, konsumen dan pelaku pembangunan pertanian, maka konsep yang dikemukakan Monsher perlu disesuaikan dengan memperhatikan faktor sebagai berikut : a) pemanfaatan sumber daya tanpa hams merusak lingkungan; b) pemanfaatan teknologi yang senantiasa berubah; c) Pemanfaatan institusi atau lembaga yang saling menguntungkan pembangunan pertanian; d) pemanfaatan budaya untuk keberhasilan pembangunan pertanian. Selain unsur teknologi yang menjadi perhatian juga adalah masalah informasi. Penguasaan informasi saat ini sangat krusial tidak hanya bagi para petani melainkan juga bagi para pelaku pembangunan pertanian yang lain seperti penyuluh pertanian, pengurus kelembagaan dipedesaan yang mencakup para pengusaha dibidang pertanian, institusi/lembaga pendidikan, keuangan, forum komunikasi petani dan sebagainya.

\section{SIMPULAN}

Kewirausahaan dapat dipandang sebagai titik temunya peluang dengan persiapan mulai dari pengembangan ide, mewujudkan impian, mengalokasi sumber daya yang terbatas dan memberi nilai lebih dirinya dan masyarakat

Krisis ekonomi lebih banyak melanda usaha - uasaha yang memiliki komponen impor yang lebih tinggi dan sebaliknya memben peluang pada usaha - usaha yang berbasis sumber daya lokal yang berpotensi ekspor dan melakukan sinergisme termasuk didalamnya adalah usaha dibidang pertanian
Dalam rangaka ketahanan ekonomi rakyat pedesaan, petani perlu meningkatkan skala usaha yang ekonomis. Pendekatannya harus secara bertahap dilakukan agar pemilikan lahan dan usaha pertanian menjadi usaha pokok keluarga untuk mewujudkan kemandirian. Tahap - tahap yang dilalui dapat berkembang dari Subsistence Existence - Survival - Sustainable.

Menghadapi era globalisasi saat ini dan mendatang, sangat diperlukan penguasaan teknologi dan informasi.

Globalisasi dan perubahan tatanan perekonomian dunia yang sedemikian cepat menurut dunia usaha untuk mengembangkan usaha pertanian efisien, kompotitif, produktif, viable dan melakukan sinergi serta marketing strategi.

Keterbatasan kualitas sumber daya menusia terutama yang berhubungan dengan kemampuan teknis dan manajerial perlu dilakukan upaya peningkatan semangat, jiwa dan kemampuan kewirausahaan.

\section{DAFTAR PUSTAKA}

Arifin, B. 2005. Pembangunan Pertanian : Paradigma Kebiajakan dan Strategi Revitalisasi. Jakarta : PT. Gramedia Widiasarana Indonesia

Husodo, S.Y. 2004. Pertanian Mandiri. Penebar Swadaya. Jakarta

Kasmir. 2006. Kewirausahaan. PT. Raja Grafindo Persada. Jakarta

Krisnamukti, B. 2005. Langkah Sukses Memulai Agribisnis. Penebar Swadaya. Jakarta

Prawirokusumo, S. 2001. Ekonomi Rakyat (Konsep, Kebijakan, dan Strategi). BPFE. Yogyakarta

Soekartawi. 2005. Agribisnis : Teori dan Aplikasinya. PT. Raja Grafindo Persada. Jakarta

2001. Pengantar Agroindustri. PT. Raja Grafindo Persada. Jakarta 